\title{
China in India's Neighbourhood: Connectivity, Political Messaging and Military Diplomacy
}

Jabin T Jacob*

\section{Abstract}

This essay examines three approaches in Chinese foreign and security policies at work in India's neighbourhood with the help of three brief case studies involving Nepal, Bhutan and Sri Lanka. The first looks at how China has engaged with Nepal through connectivity projects as part of the Belt and Road Initiative. The second case study looks at Chinese attention to Bhutan especially in the context of the Doklam conflict with Indian in mid-2017. The third and final case study describes Beijing's military diplomacy with Sri Lanka. These case studies provide an overview of the range of Chinese activities, approaches and interests in South Asia that New Delhi often has trouble appreciating or accepting. This article argues that accepting the reality of these Chinese approaches and understanding them are essential for India to rethink and reinvigorate its own neighbourhood policy.

Keywords: Chinese Foreign Policy; South Asia; Infrastructure Development; Military Diplomacy; Propaganda

\section{Introduction}

The Chinese have embarked on a path to gaining influence in Asia that is radically different in its approach from the United States.

* Department of International Relations and Governance Studies, Shiv Nadar University, Greater Noida \& National Maritime Foundation, New Delhi, India; jabin.jacob@snu.edu.in 
The Belt and Road Initiative (BRI) is its most prominent and widely-discussed expressions but there are other alternative approaches. One is the older, traditional means of political messaging and signalling through the Chinese media and diplomacy while another is a relatively recent but still older than the BRI approach of increasing military exchanges and ties with other countries. This article examines each of these approaches in Chinese foreign and security policies working in India's neighbourhood with the help of three brief case studies. The first looks at how China has engaged with Nepal through the connectivity projects under the rubric of the BRI. The second looks at how Bhutan has been approached by China in the wake of the Doklam conflict with Indian in mid-2017 while the third and final section looks at how Beijing has used military diplomacy with Sri Lanka to improve its standing in that country. While these case studies are by no means comprehensive, they do, nevertheless, provide a glimpse of the range of China's activities, approaches and interests in South Asia that India often has trouble appreciating or accepting. This article argues that accepting the reality of these approaches and understanding them is essential if India is to reinvigorate her approaches to neighbours in the region.

\subsection{Connectivity Cooperation: The Case of Nepal}

China and Nepal signed a transportation agreement in Kathmandu on 7 September 2018, which would allow Nepal to trade with four seaports and three dry ports in China - Tianjin, Shenzhen, Lianyungang, Zhanjiang and the dry ports of Lanzhou, Lhasa and Shigatse (Yuan \& Li, 2018). This was the finalization of a transit transport agreement reached by Nepalese Prime Minister KP Oli during his visit to China in 2016 in his first tenure as Prime Minister. The significance of this development is that the visit and this agreement are directly linked to the Nepalese search for alternatives to Indian control over its economic lifelines in the wake of the 2015 Indian fuel blockade on Nepal during the first Oli tenure. Indeed, it could be argued that the fuel blockade has been a turning point for the worse in the history of India-Nepal relations and an opportunity now being exploited to the hilt by the Chinese gradually but substantially. 
It is evident that the Chinese-led BRI (Belt and Road Initiative) is going to be the framework for China-Nepal connectivity projects and cooperation (China Tibet News, September 8, 2018). Nepal is laying much in store in the planned increased connectivity with China via port, road, railway, aviation and communications networks under the 'overarching framework of trans-Himalayan Multi-Dimensional Connectivity Network' (Ministry of Foreign Affairs, Nepal, 2018). In addition to the proposed China-Nepal railway line between Xigaze and Kathmandu expected to be completed by 2022, Chinese analysts are also highlighting the Sichuan-Tibet railway, which is expected to boost both Tibet's connectivity with the rest of China and integration with South Asia by increasing the flow of both commodities as well as of tourists to Nepal (and to India) (Li, 2018). Nepal's fledgeling aviation sector is also depending on buying Chinese aircraft to increase capacity and routes served (Xinhua, January 31, 2018). In January 2018, China Telecom Group Corporation and the Nepalese Ministry for Information and Communication inaugurated the Nepal-China cross-border optical fibre link in Kathmandu, providing an alternate Internet gateway to the Himalayan nation in addition to those through India (Yuan, 2018).

In May 2017, TAR and Nepalese enterprises signed two cooperation projects - the Sino-Nepalese Friendship Industrial Park and the China Tibet Autonomous Region-Nepal Cultural Industry Park (Wang, 2018). Chinese involvement in Nepal's energy sector is also growing. In addition to hydel projects, China is also helping the renewable energy sector in Nepal, for instance, through the donation of 32,000 sets of household solar power generation systems in January 2018 (Xinhua a, January 21, 2018). Among other developments in China-Nepal relations are agreements for the reconstruction of the building of the Consulate General of Nepal in Lhasa and the reconstruction of the Zhangmu Friendship Bridge and the Jijiang Thermal Cable Bridge (Wang, 2018).

The Speaker of the Nepalese lower house of Parliament, Krishna Bahadur Mahara, attended the 4th China Tibet Tourism Culture International Expo, co-sponsored by the Ministry of Culture and Tourism and the TAR government in 2018. One of the objectives of the Expo was to "build an important channel for opening up to 
South Asia"(China Tibet News, September 8, 2018). Mahara for his part said, "Tibet has become an important gateway for bilateral exchanges between Nepal and China in the field of trade, tourism, culture and other fields. Nepal attaches great importance to this Expo and hopes to promote business and tourism development between the two countries" (China Tibet News, September 8, 2018).

Despite the efforts that India's Narendra Modi government has put into the relationship with Nepal since KP Oli returned to power as Prime Minister of Nepal - there have been multiple high-level visits - the legacy of India's fuel blockade of Nepal in 2015 appears difficult to overcome. While bilateral agreements continue to be signed, Sino-Nepalese interactions are now perhaps of equal if not more significance for Nepalese politicians.

The Oli government also reversed the decision of its predecessor to cancel the award of the Buddhi Gandaki hydroelectric project to China. It must be remembered that it was on the eve of the general elections that in November 2017, that the then Nepalese Deputy Prime Minister and Energy Minister Kamal Thapa had announced the cancellation of the project saying that the agreement with the Chinese company was 'marred by irregularities' and therefore, rejected by a parliamentary committee (Thapa, 2017).The Oli plan to reverse this decision had been in the works even before the government was sworn in (Zheng, 2017). Later, in a speech on the BRI in September this year, Oli said he 'would like to dispel apprehensions, if any, by stating that the Government will be solely guided by the national interest in selecting or accepting projects and programmes under any bilateral, regional or multilateral mechanisms' (Government of Nepal, 2018).

From the Chinese perspective meanwhile, at the signing of the aforementioned transportation agreement in Nepal, one of their interlocutors stated, 'the agreement reached between China and Nepal shows that China has the ability and means to promote interoperability with South Asia. On the other hand, it also has a demonstration effect for the countries in the region, especially small and medium-sized countries' (Yuan \& Li, 2018). This is clearly signalling to India that Beijing would not respect the former's sphere of influence in South Asia. 
It is also significant that at the 4th China Tibet Tourism Culture International Expo, Linzhi was one of the venues (China Tibet News, September 11, 2018). Linzhi is one of the two prefecturelevel cities in the TAR that claims administrative jurisdiction over parts of Arunachal Pradesh. The Expo also saw the organization of the first "Himalayan Belt and Road" Cooperation Forum among other activities (China Tibet News, September 11, 2018), a formulation that is designed in a manner to draw objections from the Indians given their opposition to BRI itself.

The aforementioned Oli speech deserves closer attention. The speech was made at an international conference on the BRI in Tribhuvan University in September 2018 and titled, 'Opportunities and Implications for Nepal and the Region' (Government of Nepal, 2018). In it, Prime Minister Oli appeared to lay out his position more openly in favour of the Chinese initiative that India has bitterly opposed.

One, he used the CPC template of calling the BRI 'a visionary initiative launched ... by Chinese President Xi Jinping' - note the reference to the individual rather than the country. He also picked out pet themes from the lexicon of the BRI referring to 'community of common interest' and 'community of common destiny'. Like any leader of a small nation under pressure from its other neighbours or on a difficult political wicket personally, Oli appeared to choose a personalised approach to China and to $\mathrm{Xi}$.

Two, he talked of the BRI as "an important step that aims at promoting connectivity and cooperation among the countries in the region and beyond", implicitly ignoring both India's sovereignty concerns with respect to the CPEC as well as its concerns over transparency, accountability and any number of other issues over with the BRI as a whole. Besides praising Chinese rapid economic growth and highlighting how it could serve as a model for Nepal, Oli specifically stated that the "BRI can also be instrumental in implementing the Sustainable Development Goals. This way, it will serve the global goods in the interest of humanity" (Government of Nepal, 2018). However, the data now becoming available about the BRI five years since its launch suggests exactly the opposite and Oli and his advisers must have been aware of this. Looking to China as a model for economic development for Nepal is not an uncommon 
theme among Nepalese leaders. For instance, former Nepalese Deputy Prime Minister Sujata Koirala, a leader from the opposition Nepali Congress, would say at another seminar in Kathmandu organised earlier in January 2018, that "China has achieved astounding economic growth while at the same it has reduced the poverty rate significantly in recent years. These positive transformations in China are exemplary especially for other least developed and smaller countries like Nepal" (Xinhua b, January 21, 2018).

Three, Oli buttressed the international narrative the Chinese are seeking to promote in opposition to the United States, saying "increasing protectionist tendencies are eroding the rule-based multilateral trading system" and that "BRI can be an option for openness and shared benefits" (Government of Nepal, 2018). In this, he was simply copying the Chinese code for the Donald Trump administration's apparent protectionist turn and trade war against China and the belief that it was the BRI that was next game in town.

While Oli did devote some time in his speech to Nepal's building up of connectivity with India and referred to SAARC and BIMSTEC as important platforms for "multidimensional regional connectivity', he also reiterated the need to 'make these regional organizations fully functional and result-oriented" (Government of Nepal, 2018). In other words, he reminded the audience of their failure thus far, which might be a fair enough assessment given the number of years these organisations have been in existence without much result. At the same time, Oli was also imbalanced in terms of his approach given that he did not find anything to criticise in the BRI when there was evidence aplenty even from his own neighbourhood of debt-traps and parting with strategic equity as a result of BRI projects, if not yet in Nepal's own case.

\section{Political Messaging: The Case of Bhutan}

The role of political messaging and persuasion in China's diplomacy generally and in South Asia more specifically should not be discounted for it both offers indicators or signals of as well as reflects Chinese approaches and thinking on a host of issues. 
Just under a year after the Doklam standoff in Bhutan between India and China ended, Chinese Vice Foreign Minister, Kong Xuanyou, became the highest-ranking Chinese official yet to visit Bhutan when he landed in Thimphu on 22 July 2018. Officials from the Chinese embassy in Delhi have, however, frequented Bhutan earlier and it is noteworthy that the former Chinese ambassador to India Luo Zhaohui had visited Thimphu as early as January 2017 as had his wife, also a member of the staff at the Embassy (Roy, 2018).

The visit by Kong, whose position is the Chinese equivalent to India's Foreign Secretary, should be seen as part of a logical series of Chinese steps preceding and following Doklam. In fact, it could well be argued that this expansion of China's relationship with Bhutan was precisely the objective behind the Chinese provocations at Doklam. For why else, would any thinking Chinese general put his troops in a tactically disadvantageous position in which there was only going to be one side coming out successful, namely India? Note also that the Chinese chose the one area of their dispute with Bhutan that also involved Indian interests. The objective could have been to make it appear - at least to the outside world if not to the Bhutanese themselves - that the Chinese were not forcing matters with Bhutan itself but were being set upon by the Indians. Following Doklam, China could legitimately claim its security interests were at stake and that it had to have a presence in and engagement with Bhutan. Former Indian NSA, Shivshankar Menon appeared to hint as much in an interview saying 'I think a lot of [Doklam] was designed actually for its effect on Bhutan' (The Print, 2018).

Perhaps, Indians military strategists have carried on for too long, under the mistaken impression, in the age of nuclear weapons and precision munitions, high-quality surveillance and sustained propaganda, that the ability to sever the Chicken's Neck corridor remains a significant objective of war for the Chinese. It might be important but it is not significant. The record should show that visual or physical access to the Corridor is not the only way to ensure India's Northeast remains politically fragile and strategically unstable in a manner that serves China's interests. 
The elements of political persuasion employed by the Chinese visà-vis the India-Bhutan relationship can also be gleaned from their media coverage of the tiny Himalayan country.

In general, Chinese articles on Bhutan are of two kinds. The first that deal with the bilateral situation also take frequent direct or oblique potshots at India's apparently hegemonic role in the country. This probably picked up during the Doklam standoff with one Global Times editorial openly suggesting 'China should lead the international community in restoring Bhutan's diplomatic and defense sovereignty' (Global Times a, 2017) while the People's Daily included articles with such bellicose titles as, 'India must not flirt with disaster' and 'India is playing with fire, and it could get burned' (Stone, 2013).

During his visit, Kong made it a point to state that China respected Bhutan's independence, sovereignty and territorial integrity and that his country attached great importance to the 'traditional friendship' with Bhutan. These points were repeated by a Chinese analyst of India, Hu Zhiyong, who then added that 'So far Bhutan cannot completely get rid of India's influence on politics, economy, diplomacy and security' (Xu, 2018).

An op-ed from March in the same publication was dismissive of the chances of success of India's neighbourhood diplomacy focused on Bhutan, again quoting the aforementioned Hu (Zhang, 2018). Other articles have tried to push the line India's neighbours, including Bhutan, are unhappy with India's apparent 'sense of superiority' (Huang, 2018), and that India 'stop treating those small countries around it as its mistresses and showing no tolerance when they interact with other major powers' (Global Times b, 2017), while sometimes trying to take the edge off by referring to India's and China's shared history of suffering from colonialism and suggesting 'India should strike sincere friendship with China and abandon the mentality that Beijing is its biggest rival'(Cheng, 2018). This last might only be a grudging acknowledgement of India's historical advantages in the region even if its smaller neighbours did not always like it.

Chinese media also carries a fair number of references to Bhutan's bilateral ties with other countries besides India, perhaps as a way of 
bringing the tiny Himalayan nation to both domestic attention and international attention as an entity out of India's orbit (Xinhua, April 17, 2017).

Another set of articles focus on Bhutan's social and development experience with articles covering, for instance, environmental issues (Xinhua c January 29; Xinhua May 10, June 4, 2018). One article, for instance, talks about the apparent increasing popularity of WeChat in Bhutan used for both personal communications and commercial purposes (Xinhua, February 2, 2018). This, in turn, should concern Indian policymakers, who along with those from liberal democracies elsewhere are beginning to see the extent of the challenge posed by China's dominance in telecom and communications technologies. The controversy over the links of the Chinese telecom major Huawei and its linkages and potential subservience to the Chinese state is a case in point that highlights China's threats to information security, accuracy and even, access in other countries.

Overall, Chinese media attention to Bhutan remains sporadic but how India reacts to Chinese moves might well determine the direction and trends of this attention.

\section{Military Diplomacy: The Case of Sri Lanka}

Increased military exchanges and diplomacy is another key feature of China's engagement in South Asia.

In 2018, China announced the gifting of a naval frigate to Sri Lanka. This comes in addition to other elements of military engagement such as various Chinese training courses for all three services in the Sri Lankan armed forces and a Chinese-funded auditorium complex at the Sri Lanka Military Academy (Rutnam, 2018). The announcement came at a reception held in Colombo to mark the 91st anniversary of the founding of the PLA and is once again part of the signature $\mathrm{Xi}$ style - while China has decided to ameliorate criticism of its BRI by the gift of money, it is also simultaneously declaring that it will not rein in its ambitions or lay low even for a time in the security aspects of its outreach to Sri Lanka, South Asia, or the world. 
In other words, the sensitivity of such military deals is precisely how China signals that no matter the bad press or its own situation at home, it will push back against any power that chooses to believe China can and should be boxed in geographically or politically. And it clearly does believe that India's ambition to seek the hegemony of the Indian Ocean is very clear (Sina Military, April 18, 2018). Of course, it is also convenient that in this particular case, India while the dominant power in South Asia cannot similarly push back against China in the latter's sphere of influence in East Asia.

The gift of a naval frigate is significant for the Sri Lankan navy does not currently operate a frigate. Frigates are generally designed for protection duties while accompanying other warships and merchant ships, including especially hunting submarines. It is, therefore, conceivable, that as part of expanding Sino-Sri Lankan military cooperation, Chinese-supplied frigates of the Sri Lankan Navy will accompany Chinese naval convoys or participate in Chinese anti-piracy missions. Additionally, the business of training Sri Lankan sailors for handling the new acquisition will increase Chinese military presence in Sri Lanka and the Indian Ocean.

There is a still subtler Chinese military approach to Sri Lanka in the form of educational and training exchanges and research collaborations. A case in point is the setting up of the China-Sri Lanka Joint Centre for Education and Research (CSL-CER) at the University of Ruhuna in southern Sri Lanka. The centre is the result of an MoU between the two countries signed during Chinese President Xi Jinping's visit to Sri Lanka in September 2014. The point to note is that the Chinese partner for the collaboration is the South China Sea Institute of Oceanology (SCSIO) of the Chinese Academy of Sciences (Xinhua, September 29, 2018).

On the surface, the activities of the SCSIO appear entirely above board in the form of academic staff and student exchange and the establishment of a fully-automated weather station, and a joint observatory for wave and tidal measurements. However, SCSIO has a much bigger role in Chinese security policies than is immediately apparent from its English-language website. The Chinese language website shows that it is engaged in 'national defense safety construction projects' including the massive Chinese 
reclamation projects on disputed features in the South China Sea in both the Paracels and Spratlys. The SCSIO, in fact, highlights the praise for its work from China's government, the Central Committee of the Communist Party of China and the Central Military Commission in 2018. That such an organization should have a presence - to fulfill China's desire to play 'a bigger role in the international cooperation on marine sciences and education in the Indian Ocean region' as the Xinhua reports (September 29, 2018) - has wider implications for India (Jacob, 2019).

In many ways, the military outreach to Sri Lanka forms part of a very methodical approach of the Chinese. Note for instance, that Sino-Pak naval cooperation is already of long-standing and covers India's Arabian Sea flank. With China selling submarines and frigates to the Bangladeshi navy (Sina Military, June 14, 2018), this then covers India's eastern flank in the Bay of Bengal. And support to the Sri Lankan navy helps complete the arc by covering India's southern maritime expanse. Beijing has created with limited assets and without overt belligerence, a threat profile for itself vis-à-vis India that will only keep expanding even as India finds moves to deter this Chinese naval expansion difficult.

This is for at least two reasons. One, militarily obviously, India cannot seek to equip its neighbours beyond a point both because of its lack of resources and suitable platforms to offer and for fear of these same assets being used against it or complicating other regional equations. Two, the political approach to persuading its neighbours to desist from buying or accepting Chinese military equipment is a necessarily long and slow process that cannot be achieved without India offering something else in return. In effect, Beijing has upped the costs for India's engagement in South Asia.

\section{Conclusion}

It is important for India's policymakers - its politicians, but its mandarins, especially - to let go of the sense of angst or resentment about losing India's traditional upper hand in South Asia to the Chinese. India's 'upper hand' or traditional advantages in South Asia had in many respects caused it to become arrogant and inattentive to changes in the politics and societies of its neighbours 
or to believe that these could be handled without too much effort. In the process, India left large gaps in its policymaking and outreach to its neighbours that the Chinese have exploited with speed and substantive measures, from infrastructure development to cultivating politicians of both the ruling and opposition parties to establishing direct linkages with ordinary people through public diplomacy, the offer of fully-funded delegation visits and/or scholarships or fellowships to journalists, scientists, students, artistes to military exchanges and diplomacy. Together, these initiatives have helped change attitudes to China from hostility or indifference to more positive views that see China's presence in South Asia as not just a matter of compulsion but also inevitable and natural.

If the Indian strategic community were to accept the reality, however, that China has something to contribute from economic development to technology, even if it comes under BRI framework and rid themselves of their resentment, they would also be able to come up with better approaches to resolving problems in India's bilateral relationships in South Asia as well as identify other gaps and anticipate new problems in ties. A more flexible and generous approach to its South Asian neighbours would also allow India to then raise the stakes and better persuade them to avoid more sensitive engagements or entanglements with China in the military sphere.

In essence, it is important for Indian policymakers - and its wider strategic community - to see Chinese presence in South Asia as an opportunity for India to refashion, reformulate and reimagine its approaches to foreign policy and national security involving its neighbours.

\section{References}

Cheng X. (2018, January 22). India on wrong path to regional hegemony. Global Times. Retrieved from http:// www.globaltimes.cn/ content/ 1086011.shtml

China-Sri Lanka Joint Center for Research and Education, University of Ruhuna, Sri Lanka. (n.d.). Establishment of China Sri Lanka Joint Center for Education and Research (CSL-CER). Retrieved from 
http://www.ruh.ac.lk/Uni/cslcer/mainmenu.php?menu=Events\&ev ntid=1.

Global Times. (2017, December 27). India haunted by containment delusion. Global Times. Retrieved from http:// www.globaltimes.cn/ content/ 1082384.shtml.

Global Times. (2017, July 5). China can rethink stance on Sikkim, Bhutan. Global Times. Retrieved from http:// www.globaltimes.cn/ content/ 1055088.shtml.

Huang, D. (2018, January 15). India's sense of superiority miffs neighbors. Global Times. Retrieved from http://www.globaltimes.cn/ content/ 1084905.shtml.

Jacob, J. T. (2019, February 1). Political Crisis in Sri Lanka: China and the Maritime Dimension. National Maritime Foundation. Retrieved from http://www.maritimeindia.org/View\%20Profile/63684597776900072 4.pdf.

Li X. (2018, October 11). New railway set to fuel Tibet's economy, trade with India and Nepal: experts. Global Times. Retrieved from http://www.globaltimes.cn/content/1122636.shtml.

Ministry of Foreign Affairs, Government of Nepal. (2018, September 12). Inaugural Address by Rt. Hon. Prime Minister Mr. K. P. Sharma Oli at International Conference on Belt and Road Initiative: Opportunities and Implications for Nepal and the Region. Government of Nepal. Retrieved from https://mofa.gov.np/inaugural-address-by-rt-honprime-minister-mr-k-p-sharma-oli-at-international-conference-onbelt-and-road-initiative-opportunities-and-implications-for-nepaland-the-region/.

People's Daily Online. (2017, August 8). India must not flirt with disaster. People's Daily Online. Retrieved from http:// en.people.cn/ n3/ 2017/0808/c90780-9252655.html.

Roy, S. (2018, July 24). China Minister arrives in Bhutan on first top-level visit after Doklam. The Indian Express. Retrieved from https://indianexpress.com/article/india/china-minister-arrives-inbhutan-on-first-top-level-visit-after-doklam-5272450/Rutnam, E. (2018, July 23). China to boost military ties with Sri Lanka and gift frigate. Colombo Gazette. Retrieved from https:// colombogazette.com/2018/07/23/china-to-boost-military-ties-withsri-lanka-and-gift-frigate/.

Sina Military. (2018, April 18). Yin Jun: Yindu 50 sou junjian zheng 24 xiaoshi jianshi Zhongguo haijun huhang biandui (Indian Military: 50 Indian warships monitor Chinese naval escort formations 24 hours a day). Retrieved from http://mil.news.sina.com.cn/china/2018-0418/doc-ifzihnep4320245.shtml. 
Sina Military. (2018, June 14). Yindu Yang guojia choujian Zhongguo huweijian fazhan shi zhidui xinghao quan shuliang da (Indian Ocean country's purchases of Chinese frigates mirrors their development history). Retrieved from http:// mil.news.sina.com.cn/ jssd/2018-0614/doc-ihcwpcmq6500914.shtml.

South China Sea Institute of Oceanology, Chinese Academy of Sciences. (n.d). Brief Introduction. Retrieved from http:// english.scsio.cas.cn/ $\mathrm{au} / \mathrm{bi} /$.

Stone, C. (2017, August 10). India is playing with fire, and it could get burned. People's Daily Online. Retrieved from http:// en.people.cn/ n3/2017/0810/c90000-9253612.html.

Thapa, K. (2017). @KTnepal, Twitter, 13 November 2017, https:// twitter.com/KTnepal/status/930055093423972352.

The Print. (2018, July 15). Need to take an extra step \& maintain new equilibrium with China: Ex-NSA Shivshankar Menon. The Print. Retrieved from https://theprint.in/walk-the-talk/need-to-take-anextra-step-maintain-new-equilibrium-with-china-menon/83307/. Xu, H.. (2018, July 24). China respects Bhutan to conduct independent, peaceful diplomatic policies: visiting vice foreign minister. Global Times. Retrieved from http:// www.globaltimes.cn/ content/ 1112237.shtml.

Wang Y. (2018, September 9). Zhong-Ni you you tian san dao liangli fengjing (Sino-Nepalese friendship adds three more beautiful scenes). Zhongguo Xizang Wang (Tibet.cn). Retrieved from http:// www.tibet.cn/cn/index/syyc/201809/t20180909_6245295.html.

Xinhua a. (2018, January 21). China donates solar power generation system to Nepal. Retrieved from http:// www.xinhuanet.com/ english/2018-01/21/c_136913167.htm

Xinhua b. (2018, January 21). Former deputy PM sees China's economic development as role model for Nepal. Retrieved from http:// www.xinhuanet.com/english/2018-01/21/c_136913200.htm

Xinhua c. (2018, January 29). Increasing number of vehicle poses threat to Bhutan's pristine environment. Retrieved from http:// www.xinhuanet.com/english/2018-01/29/c_136934378.htm

Xinhua. (2018, January 31). Nepali airline's team to take delivery of two more Chinese-made planes. Retrieved from http:// www. xinhuanet.com/ english/2018-01/31/c_136938579.htm

Xinhua. (2018, February 2). Chinese social media app WeChat gaining popularity in Bhutan. Retrieved from http:// www.xinhuanet.com/ english/2017-04/17/c_136216105.htm. 
Xinhua. (2018, March 10). Bhutan awarded world's Sustainable Destinations' Earth Award. Retrieved from http:// www.xinhuanet.com/ english/2018-03/10/c_137029914.htm

Xinhua. (2017, April 17). Bangladeshi PM's three-day Bhutan visit to focus on six deals. Retrieved from http:// www.xinhuanet.com/ english/ 2017-04/17/c_136216105.htm.

Xinhua. (2018, June 4). Bhutan to observe "World Environment Day" with traffic free day. Retrieved from http:// www.xinhuanet.com/ english/2018-06/04/c_137229575.htm

Xinhua. (2018, September 29). China invests in new center in Sri Lanka to strengthen collaboration on marine sciences. Retrieved from http:// www.xinhuanet.com/english/2018-09/29/c_137501493.htm.

Yuan J. (2018, January 16). Lijing san nian ban Zhong-Ni kua jing hulianwang guanglan zhengshi kaitong (After three and a half years, China-Nepal cross-border Internet cable is officially opened). Renmin Ribao (People's Daily). Retrieved from http:// ydyl.people.com.cn/ n1/2018/0115/c411946-29764122.html.

Yuan Z. \& Li S. (2018, September 10). Zhongguo he Nibo'erqian“lishi ting"gangkouxieyi. Yin mei hen suan (China and Nepal sign "historic" port agreement. Indian media is very displeased). Huanqiu Wang: Junshi (Global Times: Military). Retrieved from http:// mil. huanqiu.com/world/2018-09/12973419.html?agt=15422.

Zhang, H. (2018, March 12). Indian strategy focusing on South Asian diplomacy likely to fail: analyst. Global Times. Retrieved from http:// www.globaltimes.cn/ content/1092920.shtml.

Zheng, S. (2017, December 14). Nepal's Government-in-waiting To Revive Scrapped Chinese Dam Project. South China Morning Post. Retrieved from https://www.scmp.com/news/china/diplomacy-defence/ article/2124321/nepals-government-waiting-revive-scrappedchinese-dam.

Zhongguo Xizang Xinwen Wang (China Tibet News). (2018, September 8). Di si jie Zhongguo Xizang lüyou wenhua guoji bolanhui long chong kaimu (The 4th China Tibet Tourism Culture International Expo has a grand inauguration). Retrieved from http:// www.xzxw.com/ zw/ 201809/t20180908_2359362.html.

Zhongguo Xizang Xinwen Wang (China Tibet News). (2018, September 11). Wu Yingjie deng lingdao fenbie huijian Nibo'er Zhongyiyuan yizhang, Mengguguo Wulanbatuo shi yizhang ji waiguo zhu Hua shijie tuan (Wu Yingjie and other leaders meet individually with the speaker of the Nepalese House of Representatives, the Speaker of the Ulaanbaatar City of Mongolia and diplomatic envoys of various 
countries to China). Retrieved from http:// www.xzxw.com/ zw/ zwyw/201809/t20180911_2363891.html.

Zhongguo Kexueyuan Nanhai Haiyang Yanjiusuo (South China Sea Institute of Oceanology, Chinese Academy of Sciences). (n.d.). Jigoujieshao (Introduction of the Organization). Retrieved from http:// www.scsio.cas.cn/gkjj/jgjj/ 